\title{
Cell-Specific Expression and Lipopolysaccharide-Induced Regulation of Tumor Necrosis Factor $\alpha$ (TNF $\alpha$ ) and TNF Receptors in Rat Dorsal Root Ganglion
}

\author{
Yanzhang Li, Ailing Ji, Eberhard Weihe, and Martin K.-H. Schäfer \\ Department of Molecular Neuroscience, Institute of Anatomy and Cell Biology, Philipps University Marburg, 35033 Marburg, Germany
}

\begin{abstract}
The proinflammatory and lipopolysaccharide (LPS)-inducible cytokine tumor necrosis factor $\alpha$ (TNF $\alpha$ ) has been shown to enhance primary sensory nociceptive signaling. However, the precise cellular sites of TNF $\alpha$ and TNF receptor synthesis are still a matter of controversy. Therefore, we differentiated the neuronal and non-neuronal sites of TNF $\alpha$, TNFR1, and TNFR2 mRNA synthesis in dorsal root ganglion (DRG) of control rats and evaluated how their expression is altered under systemic challenge with LPS. In situ hybridization (ISH), RT-PCR analysis of laser-microdissected cells, and immunocytochemistry revealed absence of TNF $\alpha$ from DRG neurons and LPS-induced expression of TNF $\alpha$ exclusively in a subpopulation of non-neuronal DRG cells. Using RT-PCR and Northern blotting TNFR1 and TNFR2 mRNAs were found to be constitutively expressed and increased after LPS. TNFR1 mRNA was expressed in virtually all neurons and in non-neuronal cells with increased levels after LPS in both. TNFR2 was exclusively expressed and regulated in nonneuronal cells. RT-PCR analysis of microdissected DRG neurons and of the sensory neuronal cell line F11 confirmed the neuronal expression of TNFR1 and excluded that of TNFR2. Double ISH revealed varying levels of TNFR1 mRNA in virtually all DRG neurons including putative nociceptive neurons coding for calcitonin gene-related peptide, substance $\mathrm{P}$, or vanilloid receptor 1 . Taken together, we provide evidence that non-neuronally synthesized TNF $\alpha$ may directly act on primary afferent neurons via TNFR1 but not TNFR2. This is likely to be relevant under conditions of inflammatory pain and infections accompanied by widespread TNF $\alpha$ synthesis and release and may drive sickness behavior.
\end{abstract}

Key words: cytokine; neuroimmune; primary afferent; neuropeptide; vanilloid receptor; pain

\section{Introduction}

Tumor necrosis factor $\alpha(\mathrm{TNF} \alpha)$, a proinflammatory cytokine with pleiotropic functions, is involved in nociceptive responses causing hyperalgesia (Cunha et al., 1992; Watkins et al., 1995; Ignatowski et al., 1999; Junger and Sorkin, 2000). In chronic constriction injury (CCI), an animal model of injury-induced painful mononeuropathy, inhibition of TNF $\alpha$ synthesis and release results in reduced pain behavior (Lindenlaub et al., 2000). In rat dorsal root ganglion (DRG), acute topical application of TNF $\alpha$ increases the firing rate of sensory neurons in normal rats and rats subjected to chronic DRG compression (Liu et al., 2002).

During an immune response TNF $\alpha$ production is enhanced in cells of the monocyte-macrophage lineage and in T-cells (Bette et al., 1993). In the CNS microglia and astrocytes are believed to be the primary cellular sources of TNF $\alpha$ expression (Hopkins and Rothwell, 1995). In peripheral nerve injury, Schwann cells have

Received June 17, 2004; revised Sept. 9, 2004; accepted Sept. 10, 2004.

This study was supported in part by grants from the Deutsche Forschungsgemeinschaft DFG SFB 297 and the Bundesministerium für Bildung und Forschung 01GS01118. We thank Heike Reichert-Preibsch, Michael Schneider, and Marion Zibuschka for excellent technical assistance.

Correspondence should be addressed to Martin K.-H. Schäfer, Department of Molecular Neuroscience, Institute of Anatomy and Cell Biology, Philipps University Marburg, Robert-Koch-Strasse 8, 35033 Marburg, Germany. E-mail: mkh.schafer@staff.uni-marburg.de.

DOI:10.1523/JNEUROSCI.2392-04.2004

Copyright $\odot 2004$ Society for Neuroscience $\quad$ 0270-6474/04/249623-09\$15.00/0 been reported to produce TNF $\alpha$ (Wagner and Myers, 1996). TNF $\alpha$ mRNA has been shown to be increased in axotomized rat DRG but its cellular source has not been determined (Murphy et al., 1995). Based on immunocytochemical findings sensory neurons of the DRG have been suggested to contain and produce TNF $\alpha$ protein (Schafers et al., 2003b). However, whether TNF $\alpha$ protein is indeed synthesized by DRG neurons or taken up from extracellular sources is still controversial.

TNF $\alpha$ acts on two distinct subtypes of receptors, TNF receptor type 1 (TNFR1, p55) and TNF receptor type 2 (TNFR2, p75) (MacEwan, 2002). TNF $\alpha$-induced hyperalgesia seems to depend on TNFR1. TNFR1 but not TNFR2 neutralizing antibodies as well as antisense RNA against TNFR1 can reduce experimentally induced hyperalgesia (Sommer et al., 1998; Parada et al., 2003). TNFR1 and TNFR2 immunoreactivity (IR) has been reported in DRG neurons (Shubayev and Myers, 2001; Pollock et al., 2002; Schafers et al., 2003a). However, direct evidence for TNFR1 and TNFR2 biosynthesis in DRG neurons by demonstrating their mRNAs is still missing. The bacterial lipopolysaccharide (LPS) that has been reported to cause hyperalgesia (Watkins et al., 1994; Walker et al., 1996; Reeve et al., 2000), is known to enhance not only TNF $\alpha$ synthesis and release (Holst et al., 1996) but also the expression of TNFR2 and, to a lesser extent, of TNFR1 (Nadeau and Rivest, 1999). Therefore, it was our aim to discern neuronal and non-neuronal expression patterns of TNF $\alpha$, TNFR1, and 
TNFR2 in rat DRG using in situ hybridization and cell-specific laser capture microdissection techniques combined with RTPCR analysis and to examine their plasticity under conditions of LPS-induced inflammatory pain. The F11 cell line (Platika et al., 1985), a hybrid cell line from rat DRG neurons and mouse neuroblastoma cells, was used to further differentiate which of the TNF receptors is neuronally expressed. To test for the relationship of TNF receptors with presumed nociceptive DRG neurons, we performed cohybridization studies of TNFR1 with the genes encoding calcitonin gene-related peptide (CGRP), substance P (SP), or the vanilloid receptor type 1 (VR1) also referred to as TRPV1, a member of the transient receptor potential (TRP) channel family.

\section{Materials and Methods}

Animals. Animal care and procedures were conducted in accordance with institutional and National Institutes of Health guidelines. Adult (200-225 gm) male Wistar rats (Charles River, Sulzfeld, Germany) were housed in clean plastic cages on a $12 \mathrm{hr}$ light/dark cycle with ad libitum access to food and water. Rats were injected intraperitoneally with ultrapure LPS (0.5 mg/kg body weight; Escherichia coli 0111:B4, InvivoGen, San Diego, CA) and killed after 1, 3, or $6 \mathrm{hr}$ LPS stimulation by exposure to $\mathrm{CO}_{2}$. Dorsal root ganglia were rapidly removed from LPS-stimulated rats and normal rats and frozen either in liquid nitrogen for RNA extraction or by immersion in $-50^{\circ} \mathrm{C}$ cold 2 -methybutane on dry ice for histological processing and embedded in Tissue-Tek OCT compound (Sakura, Zoeterwoude, The Netherlands).

Cell culture. The F11 cell line (rat dorsal root ganglion-mouse neuroblastoma hybridoma) was provided by Dr. Mark C. Fishman (Massachusetts General Hospital, Harvard Medical School, Boston, MA). F11 cells were grown in Ham's F-12 medium, supplemented with 15\% Hyclone (Logan, UT) defined fetal bovine serum, $1 \times$ HAT (sodium hypoxanthine, aminopterin, and thymidine) supplement, and $1 \times$ antibiotic-antimycotic at $37^{\circ} \mathrm{C}$ under $5 \% \mathrm{CO}_{2}$ in tissue culture flasks. All cell culture reagents were purchased from Invitrogen (Karlsruhe, Germany). At $\sim 70-80 \%$ confluence cells were harvested for RNA and protein extractions.

Laser capture microdissection. We cut $10-\mu \mathrm{m}$-thick frozen sections through rat DRG on a Leica (Nussloch, Germany) cryostat, mounted on glass slides and stored at $-70^{\circ} \mathrm{C}$. Before microdissection, slides were stained with $0.5 \%$ cresyl violet (in $60 \mathrm{~mm}$ sodium acetate, $340 \mathrm{~mm}$ acetic acid), rinsed in distilled water, and dehydrated in 70, 96, twice in $100 \%$ isopropanol, and in xylene for $4 \mathrm{~min}$, and finally air-dried. The perikarya of DRG neurons and non-neuronal cells were microdissected separately with a PixCell II laser capture microdissection (LCM) system (Arcturus, San Diego, CA) using the following settings: laser spot size $7.5 \mu \mathrm{m}$, pulse power $70 \mathrm{~mW}$, pulse width $0.6 \mathrm{msec}$. After capturing the caps were plugged into $0.5 \mathrm{ml}$ plastic tubes containing $100 \mu \mathrm{l}$ TRIzol (Invitrogen) and stored at $-20^{\circ} \mathrm{C}$.

RNA isolation. Total RNA from pooled dorsal root ganglia, F11 cells, and microdissected cells was isolated using TRIzol reagent according to the manufacturer's protocol, treated with RNase-free DNase I (Roche Diagnostics, Mannheim, Germany) at $37^{\circ} \mathrm{C}$ for $30 \mathrm{~min}$ and columnpurified using RNeasy Mini Kit (Qiagen, Hilden, Germany). To the RNA samples from microdissected cells glycogen (Roche Diagnostics) was added as carrier to a final concentration of $250 \mu \mathrm{g} / \mathrm{ml}$ followed by phenol-chloroform purification. After precipitation the RNA pellets were washed in $70 \%$ ethanol, dissolved in RNase-free water and stored at $-70^{\circ} \mathrm{C}$. Poly $\left(\mathrm{A}^{+}\right) \mathrm{RNA}$ was prepared using the poly $\left(\mathrm{A}^{+}\right)$tract mRNA Isolation system III (Promega, Mannheim, Germany).

$R T$-PCR. cDNA was synthesized using SUPERSCRIPT II RNase $\mathrm{H}^{-}$ reverse transcriptase (Invitrogen). For PCR amplification of rat TNFR1, TNFR2, TNF $\alpha$, and GAPDH, the following gene-specific primers were used: rat TNFR1 (M63122; nt. 983-1382), forward primer: gggattcagctcctgtcaaa, reverse primer: atgaactccttccagcgtgt; (M63122, nt. 704-1902) forward primer: tcccctgtaaggagaaacagaa, reverse primer: gctttttctccacaatcacctc. Rat TNFR2 (AF498039, nt. 579-1034), forward primer: gttctctgacaccacatcatcc, reverse primer: gtcaataggtgctgctgttcaa; (AF498039, nt. 541-1242) forward primer: aatggaaacgtgatatgcagtg, reverse primer: gctacagacgttcacgatgc. Rat TNF $\alpha$ (NM 012675, nt. 15-708) forward primer: catgatccgagatgtggaact, reverse primer: tcacagagcaatgactccaaag. rat GAPDH (AF106860, nt. 119-345), forward primer: cgaccccttcattgacctcaactacatg, reverse primer: ccccggccttctccatggtggtgaagac. Hot start PCR was performed using $2 \mu \mathrm{lcDNA}$ in a total volume of $50 \mu \mathrm{l}$ containing $0.2 \mu \mathrm{M}$ primer mix, $1 \times$ PCR buffer, $1.5 \mathrm{mM} \mathrm{MgCl}_{2}, 200 \mu \mathrm{M}$ dNTPs mixture, and $1 \mathrm{U}$ AmpliTaq Gold (Roche Diagnostics) and the following program: $5 \mathrm{~min}$ at $95^{\circ} \mathrm{C}, 25-40$ cycles at $\left(30 \mathrm{sec}\right.$ at $94^{\circ} \mathrm{C}, 30 \mathrm{sec}$ at $57^{\circ} \mathrm{C}$, and $30-90 \mathrm{sec}$ at $72^{\circ} \mathrm{C}$ ) and $10 \mathrm{~min}$ extension at $72^{\circ} \mathrm{C}$.

Probes. The PCR products were subcloned into pGEM-T (Promega), their sequence identify was confirmed by double-strand DNA sequencing. Plasmid constructs were linearized by NotI and AatII for TNF $\alpha$; NotI and NcoI for TNFR1; NdeI and AatII for TNFR2; SalI and ApaI for GAPDH. Riboprobes in antisense and sense orientation were generated from linearized plasmid constructs by in vitro transcription using the appropriate RNA polymerases and ${ }^{35} \mathrm{~S}-\mathrm{UTP},{ }^{32} \mathrm{P}-\mathrm{UTP}$, or digoxigeninUTP as label. After transcription, the probes were subjected to mild alkaline hydrolysis as described (Schafer et al., 1993).

In situ hybridization histochemistry. In situ hybridization was performed as described previously (Schafer et al., 1993). Briefly, radioactive probes were diluted to $5 \times 10^{4} \mathrm{dpm} / \mu$ in hybridization solution $(3 \times$ SSC, $50 \mathrm{~mm} \mathrm{NaPO}_{4} \mathrm{pH} 7.4,10 \mathrm{~mm}$ dithiothreitol, $1 \times$ Denhardt's solution, $0.25 \mathrm{gm} / 1$ yeast tRNA, $10 \%$ dextran sulfate, and $50 \%$ formamide). Formaldehyde-fixed 14- $\mu$ m-thick frozen sections were hybridized with $25 \mu \mathrm{l}$ hybridization solution containing radioactive RNA probes at $60^{\circ} \mathrm{C}$ in formamide humid chamber box for $16 \mathrm{hr}$. After a series of washes, the sections were dehydrated in 50\% and 70\% isopropanol. For autoradiographic detection slides were coated with Kodak (Eastman Kodak, Rochester, NY) NTB-2 nuclear emulsion and exposed at $4^{\circ} \mathrm{C}$ for $7 \mathrm{~d}$ to $14 \mathrm{~d}$ in the dark. Slides were developed in Kodak D19 solution and counterstained with cresyl violet. Photographic documentation was performed under dark- and bright-field illumination using an Olympus (Hamburg, Germany) AX70 microscope.

Double in situ hybridization histochemistry. For colocalization of two mRNAs, digoxigenin-labeled riboprobes for $\alpha$ CGRP, SP, and VR1 were added to the radioactive hybridization solutions at a final concentration of $1 \mathrm{ng} / \mu \mathrm{l}$ (Mika et al., 2003). Hybridization and washing procedures were performed as described above except dehydration in 50\% and 70\% ethanol. Detection of nonradioactive hybrids was performed according to the manufacturer's instruction (nonradioactive in situ hybridization application manual; Roche Molecular Biochemical, Mannheim, Germany) using alkaline phosphatase-conjugated anti-digoxigenin Fab fragments diluted to $1 \mathrm{U} / \mathrm{ml}$ and a chromogene solution containing $0.2 \mathrm{~mm}$ 5-bromo-4-chloro-3-indolyl phosphate and $0.2 \mathrm{~mm}$ nitroblue tetrazolium salt (Roche Diagnostics). Color development was monitored under microscopic control. For detection of ${ }^{35} \mathrm{~S}$-labeled probes, the slides were coated with K5 Emulsion (ILFORD Imaging, Mobberley Chershire, UK) diluted 1:1 in water. After $7 \mathrm{~d}$ exposure at $4^{\circ} \mathrm{C}$ in the dark slides were developed as described above.

Grain counting analysis. Computer-aided grain counting was performed on autoradiograms counterstained with cresyl violet under bright-field conditions at $670 \times$ magnification using a digital Camera (Spot RT Slider, Diagnostics Instruments Inc., Sterling Heights, MI) and the microcomputer imaging device Image Analysis software (Imaging Research Inc, St. Catharines, Ontario, Canada). All image analysis was performed by the same observer who was not aware of the treatment group. From three sections per group, neuronal ( $n=391$, controls; $n=$ 335 , LPS) and non-neuronal ( $n=129$, controls; $n=133$, LPS) cell populations were analyzed. The cross-sectional area of each perikaryon with a visible nucleus was outlined, and the number of grains above each outlined cell was determined using a threshold algorithm. To distinguish cell size-specific changes, DRG neurons were divided into small $(<600$ $\left.\mu \mathrm{m}^{2}\right)$, medium $\left(600-1200 \mu \mathrm{m}^{2}\right)$, and large $\left(>1200 \mu \mathrm{m}^{2}\right)$ subpopulations. Grain number was corrected using predetermined background grain density $\left(0.12 \pm 0.02\right.$ grains $\left./ \mu \mathrm{m}^{2}\right)$ on adjacent sections hybridized with the sense probe. Measurements were expressed as estimated number of silver grains per cell. Differences between groups were analyzed by one-way ANOVA followed by the Mann-Whitney $U$ test. $p$ values $<0.05$ were considered statistically significant. 

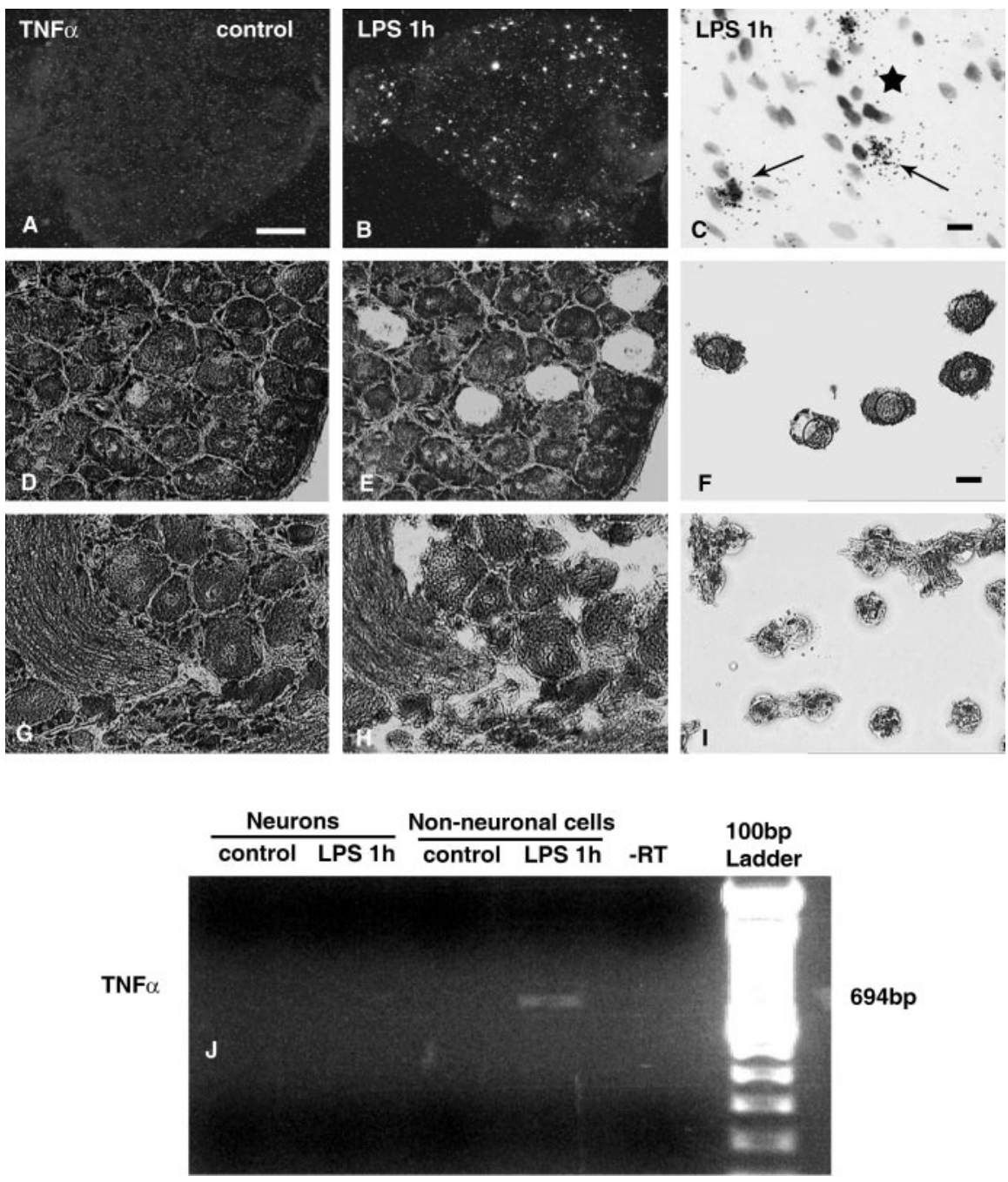

Figure 1. Detection of TNF $\alpha$ mRNA in rat DRG by in situ hybridization and in microdissected cells by RT-PCR. Dark-field autoradiograms of cryosections through rat lumbar (L4) DRG after hybridization with a ${ }^{35}$ S-labeled riboprobe specific for rat TNF $\alpha$ illustrate the lack of positive signals for TNF $\alpha$ mRNA in lumbar DRG of a normal rat $(A)$ but presence in a DRG of a rat $1 \mathrm{hr}$ after systemic LPS ( $B$ ). High-resolution bright-field micrograph depicts the accumulation of silver grains representing TNF $\alpha$ mRNA over non-neuronal cells $1 \mathrm{hr}$ after LPS treatment ( $C$, arrows). Note the absence of specific hybridization signals over neuronal perikarya $(C$, asterisk). Two hundred laser-microdissected neurons $(D, E)$ and non-neuronal cells $(G-l)$ from rat DRG were subjected to RT-PCR for TNF $\alpha$ ( ). Specific bands representing TNF $\alpha$ transcripts are detectable only in the extracts of microdissected nonneuronal cells $1 \mathrm{hr}$ after systemic LPS. Scale bars: $A, 200 \mu \mathrm{m} ; C, F, 10 \mu \mathrm{m}$.

Northern blot analysis. Aliquots of $10 \mu \mathrm{g}$ total RNA or $2 \mu \mathrm{g}$ poly $\left(\mathrm{A}^{+}\right)$ RNA were size-fractionated on a formaldehyde-denatured $1.5 \%$ agarose gel, transferred to a nylon membrane, and cross-linked. Membranes were prehybridized with NorthernMax solution (Ambion, Cambridgeshire, UK) at $68^{\circ} \mathrm{C}$ for $30 \mathrm{~min}$ and hybridized with $1-4 \times 10^{6} \mathrm{cpm} / \mathrm{ml}$ probe at $68^{\circ} \mathrm{C}$ overnight. After washing twice for 5 min with preheated $2 \times$ SSC containing $0.1 \%$ SDS and twice for $15 \mathrm{~min}$ with preheated $0.1 \times$ SSC containing $0.1 \%$ SDS at $68^{\circ} \mathrm{C}$, the membranes were exposed to Hyperfilm-MP (Amersham Pharmacia Biotech, Freiburg, Germany) for $20 \mathrm{~min}$ to $16 \mathrm{hr}$. The membranes were rehybridized with $1-4 \times$ $10^{6} \mathrm{cpm} / \mathrm{ml}$ GAPDH RNA probe to normalize for RNA loading differences. The density of the specific bands was measured by using Scion (Frederick, MD) Image Beta 4.02.

Western blot analysis. Protein was extracted from the TRIzol- treated F11 cells after RNA isolation according to the manufacturer's protocol. Protein samples (30 $\mu \mathrm{g} / \mathrm{lane})$ were separated by $12 \%$ SDS-PAGE and transferred to Hybond C extra membrane (Amersham Biosciences, Freiburg, Germany). After blocking nonspecific binding sites with 3\% bovine serum albumin (SERVA, Heidelberg, Germany) in TBST (Trisbuffered saline containing $0.1 \%$ Tween 20 ) and endogenous avidin and

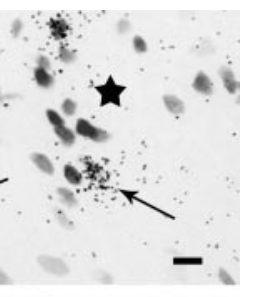

biotin with a blocking kit (Vector Laboratories, Burlingame, CA), membranes were incubated with a goat anti-rat TNFRp55 antibody (Santa Cruz Biotechnology, Heidelberg, Germany) diluted 1:5000 in TBST for $1 \mathrm{hr}$ at room temperature. After five washes for $5 \mathrm{~min}$ each, the membranes were incubated for $1 \mathrm{hr}$ with an anti-goat IgG secondary antibody (Dianova, Hamburg, Germany) diluted 1:500,000 at room temperature. After several washes in TBST, detection was performed using the $\mathrm{ABC}$ complex (Vector Laboratories) for $1 \mathrm{hr}$ at room temperature and enhanced chemiluminescence reagents (Amersham Biosciences).

Confocal laser scanning microscopy. Deparaffinized serial sections of adult DRG were collected from controls $(n=5)$ and from animals $3 \mathrm{hr}$ after LPS treatment $(n=5)$ and immersion-fixed in Bouin-Hollande solution or in $4 \%$ phosphatebuffered formaldehyde, $\mathrm{pH} 7.4$, for $24 \mathrm{hr}$. Immunofluorescence was performed by overnight incubation at room temperature with a polyclonal goat anti-murine TNF $\alpha$ antibody (PAKmTNF $\alpha$-g50; 1:100 dilution; Strathmann Biotec AG, Hamburg, Germany) together with a monoclonal IgG-purified antibody recognizing rat ED1, recognizing a macrophage-monocyte-specific antigen (1:5 dilution; Serotec, Oxford, UK). TNF $\alpha$ immunoreactivity was visualized with biotinylated anti-goat antibody (1:200 dilution; Dianova, Hamburg, Germany) at $37^{\circ} \mathrm{C}$ for 45 min, respectively, followed by an incubation with streptavidin-conjugated Alexa Fluor 488 diluted 1:200 (MoBiTec, Göttingen, Germany) at $37^{\circ} \mathrm{C}$ for $2 \mathrm{hr}$. Rat ED1 immunoreactivity was visualized with an anti-mouse antibody conjugated to Alexa Fluor 647 diluted 1:200 (MoBiTec) at $37^{\circ} \mathrm{C}$ for $2 \mathrm{hr}$. Specificity controls for TNF $\alpha$ immunostaining were performed by omission of the primary antisera, by incubation with TNF $\alpha$ preimmune serum, and by staining tissue sections from TNF $\alpha$ knock-out mice (kindly provided by B. Dietzschold, Thomas Jefferson University, Philadelphia, PA). Antibodies from other sources against murine or rat TNF $\alpha$ (Santa Cruz Biotechnology, Roche, Strathmann) were also tested, but all of them exhibited nonspecific immunostaining in rat DRG. Immunostained sections were analyzed with an Olympus Fluoview confocal laser-scanning microscope and documented as false-color confocal images.

\section{Results}

\section{Cellular distribution of TNF $\alpha$ mRNA in rat dorsal root ganglion after LPS treatment}

To determine the cellular sites of TNF $\alpha$ synthesis in the DRG and its regulation by LPS, we first investigated the expression pattern of the TNF $\alpha$ gene at the mRNA level using in situ hybridization. In sections through normal rat DRG, specific hybridization signals for TNF $\alpha$ could not be detected (Fig. 1A). However, $1 \mathrm{hr}$ after systemic LPS treatment, signals for TNF $\alpha$ were observed in many small cells scattered throughout the DRG (Fig. $1 B$ ). Microscopic analysis of cresyl violet-counterstained sections revealed that the silver grains were located over non-neuronal cells identified by their small darkly stained nuclei (Fig. 1C). When sections were hybridized with $\mathrm{TNF} \alpha$ riboprobes in sense orientation, only background labeling was observed (data not shown). 
To confirm the non-neuronal expression and to exclude a low basal expression of TNF $\alpha$ in primary sensory neurons, we performed RT-PCR on RNA extracts of microdissected DRG neurons (Fig. $1 D-F$ ) and non-neuronal cells (Fig. $1 G-I$ ). As shown in Figure $1 \mathrm{~J}$, no specific PCR product for TNF $\alpha$ could be detected in RNA extracts of microdissected DRG neurons from control or LPS-treated rats. Specific TNF $\alpha$ amplicons were also undetectable in RNA extracts of microdissected non-neuronal cells from normal rats. Only after LPS treatment a PCR product for TNF $\alpha$ could be observed in non-neuronal RNA extracts (Fig. $1 \mathrm{~J}$ ), which was confirmed by double-strand DNA sequencing.

\section{Detection of TNF $\alpha$ immunoreactivity in rat dorsal root ganglion after LPS treatment}

In Bouin-Hollande fixed DRG sections from rats $3 \mathrm{hr}$ after LPS, specific TNF $\alpha$ IR was detected in a subpopulation of nonneuronal cells surrounding primary afferent perikarya (Fig. $2 A$ ). Double immunofluorescence staining revealed that the TNF $\alpha$-IR cells were also positive for ED1 antigen (Fig. $2 B, C$ ), an established marker for cells of the macrophage-monocyte lineage (Damoiseaux et al., 1994). Specific TNF $\alpha$ IR was absent from neuronal perikarya that exhibited faint nonspecific immunostaining (Fig. $2 A)$. In DRGs from control rats we failed to detect any specific TNF $\alpha$ IR (data not shown). In formaldehyde-fixed DRG sections of both control and LPS-treated rats, we observed weak immunostaining of primary afferent perikarya and fibers when using the specific TNF $\alpha$ antisera. However, incubation with the preimmune serum produced the identical neuronal staining pattern, strongly suggesting that the neuronal immunostaining was nonspecific (data not shown).

\section{Detection of TNF receptor transcripts in rat dorsal root ganglion extracts: effects of LPS}

To investigate the expression of TNF receptors in rat DRG under basal conditions and after systemic injection of LPS, RT-PCR analysis was performed on total RNA extracts using gene-specific primers. Results are illustrated in Figure 3. TNFR1 transcripts could be detected in DRG extracts from control rats and appeared to be increased $6 \mathrm{hr}$ after LPS treatment. In contrast, only a faint band representing TNFR 2 mRNA could be detected in extracts of control rats. TNFR2 mRNA levels peaked at $3 \mathrm{hr}$ after LPS injection and decreased to control levels at $6 \mathrm{hr}$ after LPS. To determine the changes of TNFR mRNA levels indicated by the RTPCR data, we performed Northern blot analysis at time points when TNFR mRNA levels were maximal as shown in Figure 3. For TNFR1 a single transcript of $2.3 \mathrm{~kb}$ was observed, whereas three different TNFR2 mRNA species of 5.4, 4.4, and $3.1 \mathrm{~kb}$ were detected. Densitometry revealed a 2.5 -fold increase of TNFR1 mRNA in DRG $6 \mathrm{hr}$ after LPS (Fig. 4A), whereas TNFR2 mRNA levels, measuring all three transcripts, were increased $\sim 2.7$-fold 3 hr after LPS treatment (Fig. $4 B$ ).

\section{Detection of TNF receptor transcripts in microdissected DRG neurons}

To determine which TNF receptor types are expressed in neurons, we performed LCM in combination with RT-PCR (Fig. 5). Perikarya of DRG neurons were captured from rat DRG sections, and total RNA was isolated. RT-PCR analysis revealed that TNFR1 mRNA was constitutively expressed in microdissected DRG neurons, whereas TNFR2 mRNA was not (Fig. 5D).

\section{Analysis of TNF receptors in the F11 cell line}

To lend further support to the observation that TNFR1 rather than TNFR2 is expressed in primary sensory neurons, we exam-
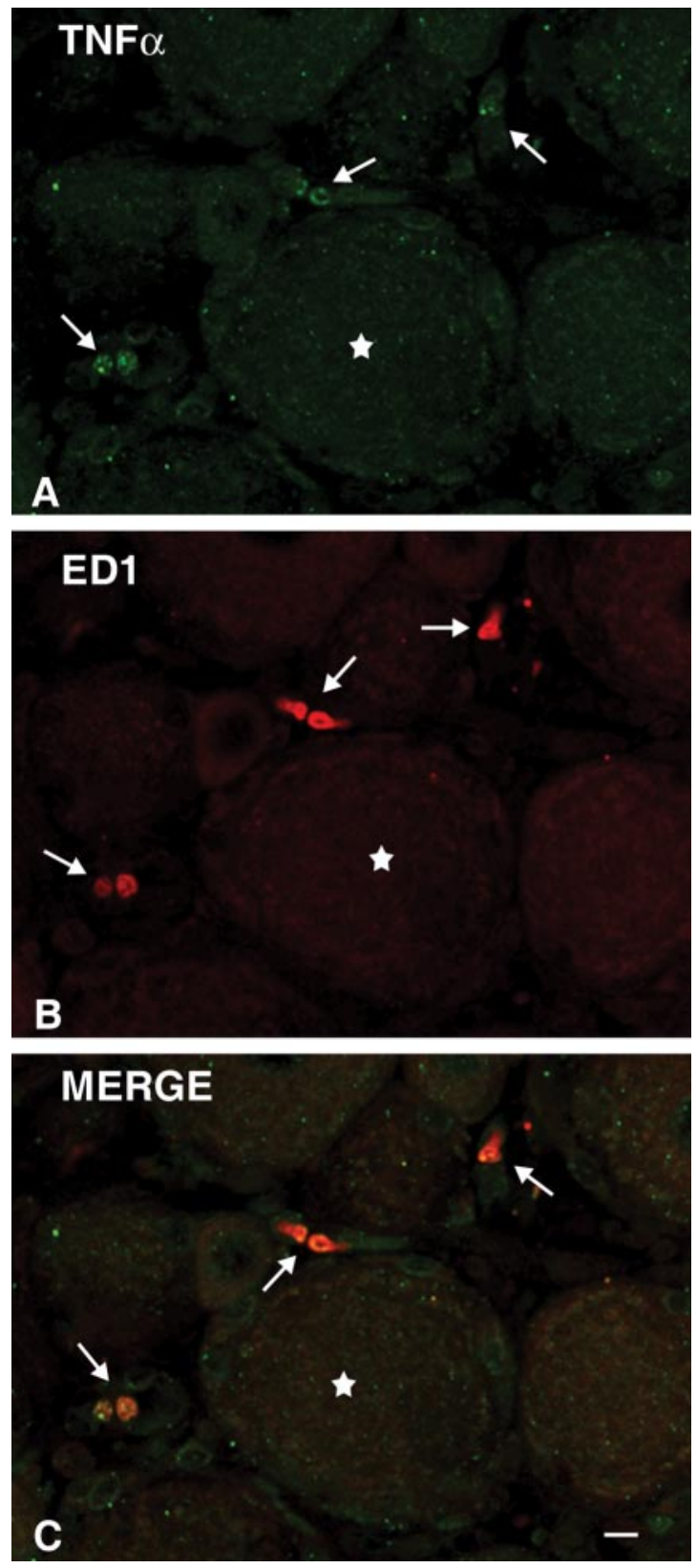

Figure 2. Detection of TNF $\alpha$ immunoreactivity in rat dorsal root ganglion ED1-positive cells after LPS treatment. TNF $\alpha$ immunoreactivity (green) was detected in rat DRG non-neuronal cells (arrows) but not in DRG neurons (asterisk) $3 \mathrm{hr}$ after LPS treatment ( $A$ ). Dual immunofluorescence with an ED1 antibody (red) (B) identified the TNF $\alpha$ IR cells as members of the macrophage-monocyte lineage (C, arrows). Scale bar, $10 \mu \mathrm{m}$.

ined the cell line F11 for TNF receptor expression. As shown in Figure $6 A$, RT-PCR analysis revealed that rat TNFR1 mRNA but not rat TNFR2 mRNA was constitutively expressed in F11 cells. In addition, using Western blot analysis a specific band of $55 \mathrm{kDa}$ representing TNFR1 protein could be demonstrated in F11 protein extracts as shown in Figure $6 B$.

\section{Cellular distribution and LPS-induced changes of TNF receptor $m R N A s$ in rat $D R G$}

To identify the DRG cells expressing TNF receptors, we performed ISH analysis on serial sections of rat lumbar dorsal root ganglion (Fig. 7). Hybridization experiments with TNFR1 or TNFR2 riboprobes in sense orientation as negative controls did 


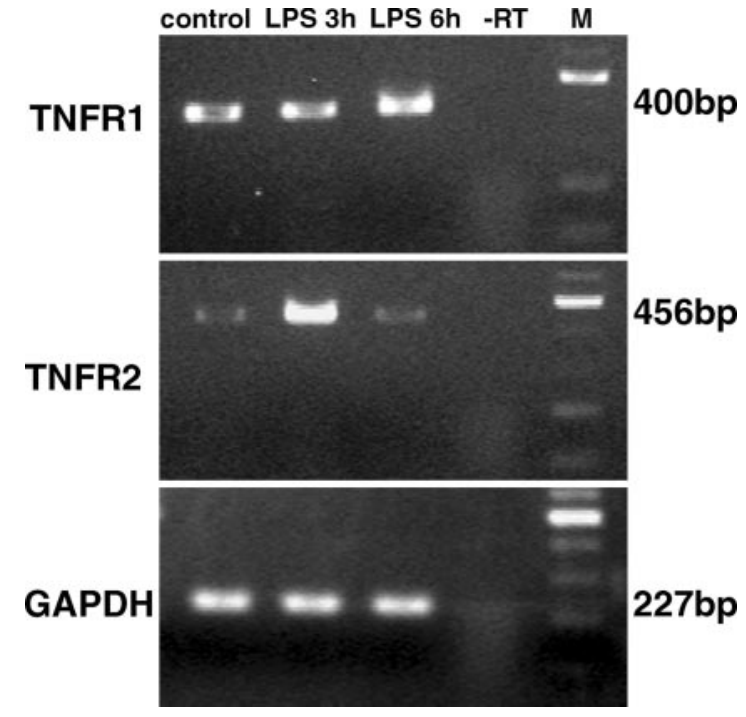

Figure 3. RT-PCR analysis of TNF receptor transcripts in extracts of dorsal root ganglion from control and LPS-treated rats. Ethidium bromide-stained agarose gel loaded with PCRs from DRG extracts. Specific amplicons for TNFR1 (top panel) are present in all lanes with a subtle increase at $6 \mathrm{hr}$ after LPS. TNFR2 mRNA (middle panel) is expressed at very low levels in control rats, but increases to peak levels at $3 \mathrm{hr}$ after LPS treatment and decreases to control levels at $6 \mathrm{hr}$ after LPS. GAPDH was used as a housekeeping gene (bottom panel). - RT, 0mission of reverse transcriptase as negative control. M, DNA size marker.
A

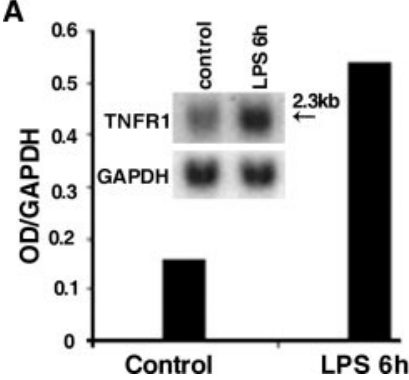

B

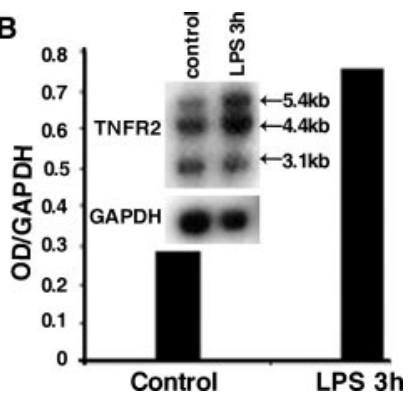

Figure 4. Northern blot analysis of TNFR1 and TNFR2 in rat DRG. $A$, For the detection of TNFR1 mRNA, $10 \mu \mathrm{g}$ of total RNA isolated from DRGs of control- or LPS-injected rats were loaded per lane. Hybridization with a TNFR1-specific ${ }^{32}$ P-labeled riboprobe yielded a single transcript of $2.3 \mathrm{~kb}$. Densitometry of autoradiograms revealed a 2.5-fold increase of TNFR1 mRNA $6 \mathrm{hr}$ after LPS as compared with control. GAPDH was used as a housekeeping gene to normalize the sample loading. Exposure time: $16 \mathrm{hr}$ for TNFR1, 2 hr for GAPDH. B, Hybridization of blots loaded with $2 \mu \mathrm{g}$ of poly $\left(\mathrm{A}^{+}\right)$RNA of rat DRG isolated from control rats or rats $3 \mathrm{hr}$ after LPS with a TNFR2-specific ${ }^{32}$ P-labeled riboprobe yielded three transcripts of 5.4, 4.4, and $3.1 \mathrm{~kb}$. Densitometry of the total signal per lane revealed a 2.7-fold increase of TNFR2 mRNA $3 \mathrm{hr}$ after LPS as compared with control. GAPDH was used as housekeeping gene for normalization of the samples differences. Exposure time: $16 \mathrm{hr}$ for TNFR2, $20 \mathrm{~min}$ for GAPDH.

not yield any specific labeling (data not shown). TNFR1 mRNA was predominantly expressed in neuronal cells (Fig. $7 A, B, E, F$ ). High-resolution microscopic analysis revealed that most DRG neurons expressed TNFR1 mRNA (Fig. 7E). TNFR1 mRNA levels appeared to differ between DRG neurons without exhibiting preference to small- or large-diameter neurons. In addition, silver grains representing TNFR1-specific hybrids were also observed over non-neuronal cells (Fig. 7E,F). Systemic LPS treatment appeared to increase TNFR1 mRNA levels in non-neuronal cells and to a smaller extent in DRG neurons as well (Fig. $7 F$ ). Quantitative image analysis of cellular TNFR1 mRNA levels using grain counting confirmed this observation (Fig. 8). In DRG neurons, a significant increase in TNFR1 mRNA levels was measured $6 \mathrm{hr}$ after LPS treatment (Fig. 8A). This change was inde-
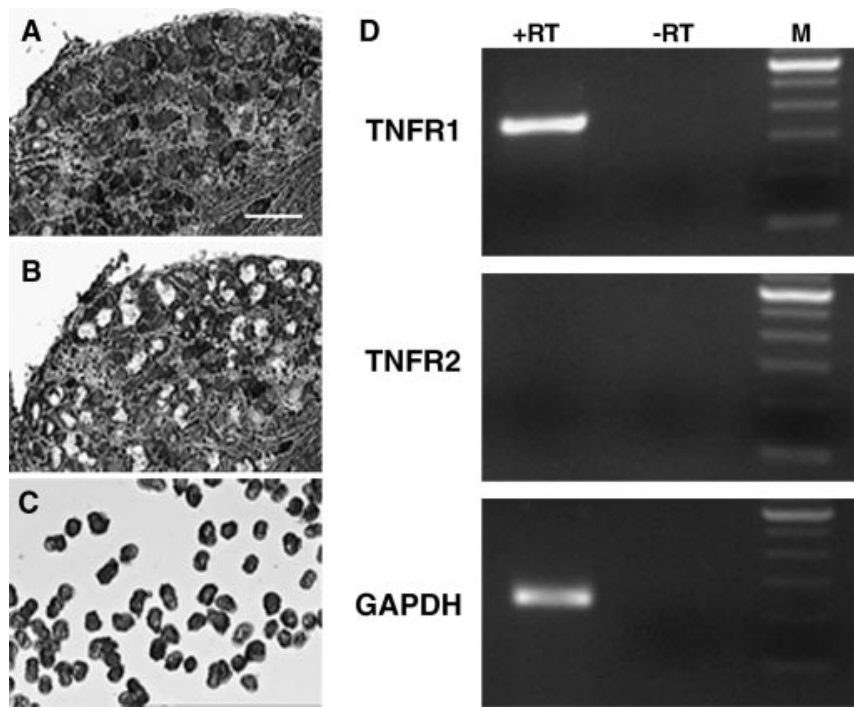

Figure 5. RT-PCR analysis of TNFR1 and TNFR2 transcripts in RNA extracts of microdissected DRG neurons. Laser capture microdissection was performed on $10-\mu \mathrm{m}$-thick cresyl violetstained cryosections of rat DRGs from normal rats. Pictures were taken from before $(A)$ and after (B) microdissection and from microdissected material (C). RT-PCR of RNA extracts from 150 microdissected neuronal perikarya revealed specific amplicons for TNFR1 but not for TNFR2 (D). GAPDH was used as a housekeeping gene detected as positive control. RT-PCR without reverse transcriptase (-RT) was performed to exclude genomic DNA contamination. A 100 bp DNA ladder was used as size marker $(M)$.

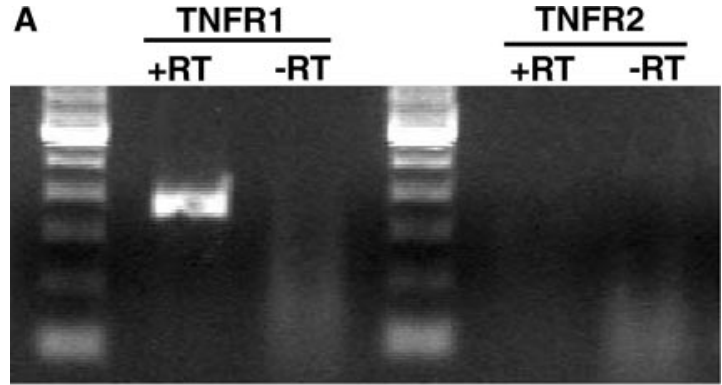

B

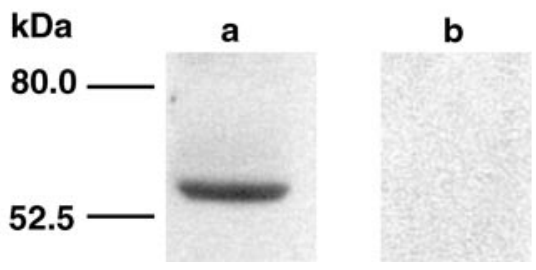

Figure 6. RT-PCR and Western blot analysis of TNF receptors in F11 cell line. $A$, In RNA extracts of F11 cells, constitutive expression of TNFR1 but not of TNFR2 mRNA is detected by RT-PCR. ( $B$ ) Western blotting shows a single band of $55 \mathrm{kDa}$ representing TNFR1 protein (lane a). Incubation with the secondary antibody revealed no immunostaining (lane b).

pendent of their size category, small [169 \pm 6 grains per cell (LPS; $n=77$ ) vs $133 \pm 8$ grains per cell (control, $n=51 ; p<0.05$ )], medium [ $281 \pm 6$ grains per cell (LPS; $n=152$ ) vs $240 \pm 7$ grains per cell (control; $n=157 ; p<0.05)$ ], and large [478 \pm 12 grains per cell (LPS; $n=106)$ vs $412 \pm 12$ grains per cell (control; $n=$ $183 ; p<0.05$ )]. In non-neuronal cells (Fig. 8 B), the LPS-induced increase of TNFR1 mRNA cells was relatively higher [41 \pm 0.7 grains per cell (LPS; $n=133$ ) vs $27 \pm 0.8$ grains per cell (control; $n=129 ; p<0.05)]$. TNFR2 mRNA was detected at very low levels in DRGs from control rats (Fig. $7 C, G$ ). Strong scattered signals for 
TNFR2 were detected $3 \mathrm{hr}$ after LPS treatment (Fig. 7D,H). Under high-resolution bright-field illumination, the silver grains for TNFR2 transcripts were exclusively observed over non-neuronal cells (Fig. 7G,H).

\section{TNFR1 expression in putative}

nociceptive neurons expressing CGRP, SP, or VR1

To test whether and at which level TNFR1 mRNA is expressed in distinct classes of DRG nociceptive neurons, we performed double labeling in situ hybridization for TNFR1 and the nociceptive receptor VR1 as well as the neuropeptides SP and CGRP known to be involved in primary afferent transmission of pain (Caterina et al., 1997; Nohr et al., 1999). TNFR1 mRNA was found in all presumed nociceptive neurons expressing CGRP (Fig. 9A), SP (Fig. 9B), or VR1 (Fig. 9C). However, TNFR1 mRNA levels exhibited substantial differences within each of these phenotypic categories of DRG neurons with no obvious level preference to any of them. In addition, TNFR1 was expressed in the majority of the remaining DRG neurons (Fig. 9A$C)$, where TNFR1 mRNA levels also varied. Thus, there was no obvious relationship of TNFR1 mRNA levels with any category of nociceptive and non-nociceptive classes of DRG neurons.

\section{Discussion}

The essential new findings of this study are: (1) LPS induces expression of TNF $\alpha$ in rat DRG exclusively in non-neuronal cells with no constitutive or LPS-inducible expression of TNF $\alpha$ in DRG neurons; (2) TNFR1 mRNA but not TNFR2 mRNA is constitutively expressed in DRG neurons and in the sensory cell line F11, and TNFR1 mRNA occurs in virtually all DRG neurons, including presumed nociceptive neurons coding for CGRP, SP, or VR1; (3) Both TNFR1 and TNFR2 mRNAs are constitutively expressed in non-neuronal DRG cells, albeit at low levels; (4) After systemic LPS neuronal and non-neuronal expression of TNFR1 mRNA and nonneuronal expression of TNFR2 mRNA in DRG are increased with TNFR2 mRNA remaining to be restricted to non-neuronal cells.

Cellular sources of TNF $\alpha$ in rat dorsal root ganglion

From their distribution pattern and relative abundance, the LPSinduced TNF $\alpha$ mRNA-expressing cells revealed in this study are most likely resident macrophages or dendritic cells but may also include Schwann cells, endoneural fibroblasts, and mast cells. These cell types have been shown to be capable of TNF $\alpha$ synthesis and to occur in the DRG and in peripheral nerves (Gordon and
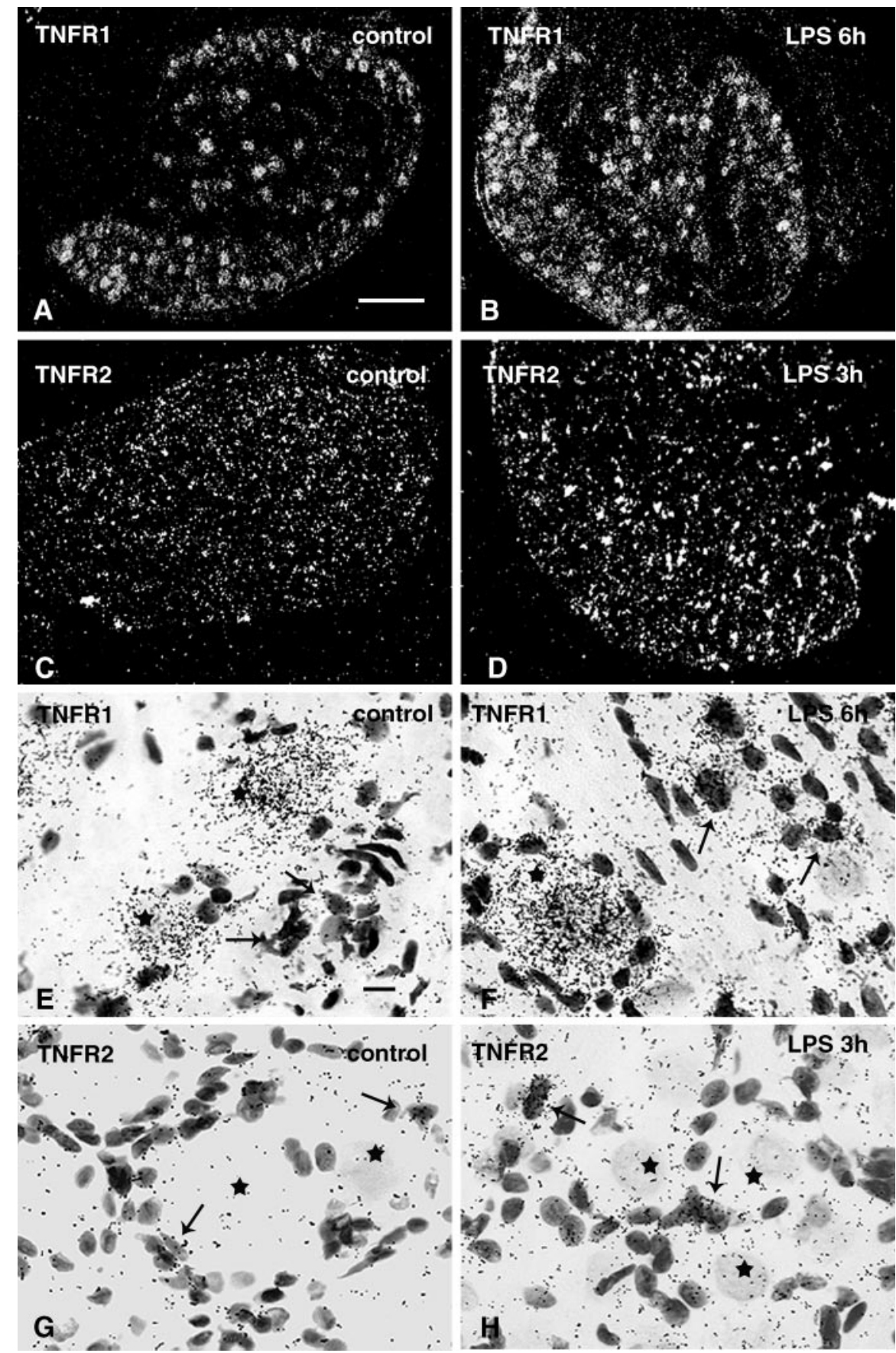

Figure 7. Cellular distribution of TNFR1 and TNFR2 mRNAs in rat DRG. Low-power dark-field autoradiograms of emulsion-coated sections illustrate constitutive and widespread expression of TNFR1 mRNA in a cryosection of a control rat $(A)$. TNFR1 hybridization signals appear to be increased $6 \mathrm{hr}$ after systemic LPS treatment $(B)$. In controls, hybridization signals for TNFR2 are very weak $(C)$, but have increased strongly $3 \mathrm{hr}$ after systemic LPS $(D)$. High-resolution bright-field images of an emulsion-coated section hybridized with the TNFR1-specific probe shows strong labeling over most large neuronal perikarya ( $E$, $F$, asterisk) and weaker labeling of the small nonneuronal cell bodies ( $E$, arrows). Note the increase of labeling intensity for TNFR1 $6 \mathrm{hr}$ after systemic LPS treatment, in particular over the small non-neuronal cell bodies ( $F$, arrows). Hybridization signals for TNFR2 are present only over non-neuronal cells ( $G$, $H$, arrows), but not over neuronal perikarya ( $G, H$, asterisk). Systemic LPS treatment enhances TNFR2 mRNA expression only in non-neuronal cells (H, arrows). Exposure times: $7 \mathrm{~d}(A, B, E, F), 10 \mathrm{~d}(C, D, G, H)$. Scale bars: $A, 200 \mu \mathrm{m} ; E, 10 \mu \mathrm{m}$.
Galli, 1991; Murwani et al., 1996; Wesselingh et al., 1997; Sommer and Schafers, 1998). Our observation of TNF $\alpha$ IR in a subpopulation of non-neuronal cells, which express the ED1 antigen, suggests that cells of the macrophage-monocyte lineage are most likely the main source for TNF $\alpha$ in rat DRG after LPS stimulation. 

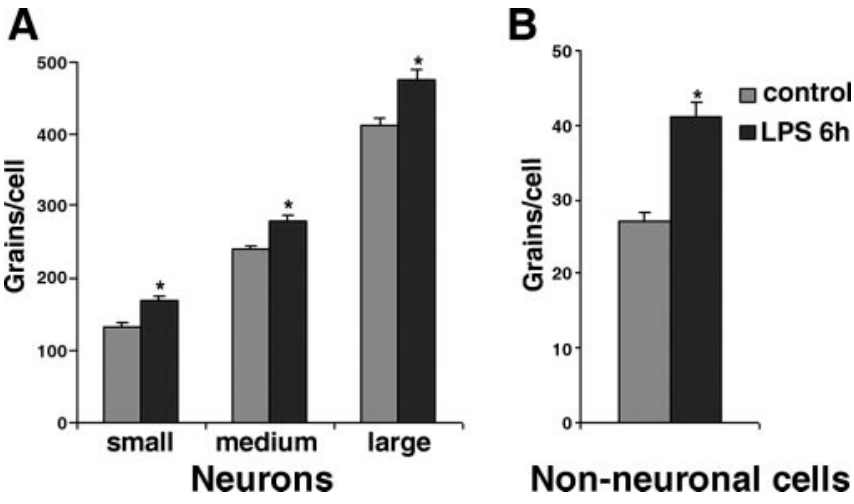

Figure 8. Grain-counting analysis of cellular TNFR1 mRNA levels in rat DRG cells. The average number of silver grains per cell representing TNFR1 mRNA was determined for neurons $(A)$ and for non-neuronal cells $(B)$ in rat DRG. Measurements in serial sections from controls $(n=3)$ and from rats $6 \mathrm{hr}$ after LPS treatment $(n=3)$ were pooled. TNFR1 mRNA is significantly increased $\left({ }^{*} p<0.05\right)$ in neurons independent of their size category, small $\left(<600 \mu \mathrm{m}^{2}\right)$, medium $\left(600-1200 \mu \mathrm{m}^{2}\right)$, and large $\left(>1200 \mu \mathrm{m}^{2}\right)$, as well as in non-neuronal cells (B).

The absence of TNF $\alpha$ mRNA and protein in DRG neurons revealed in this study is in conflict with previous reports demonstrating, based on immunocytochemistry, that TNF $\alpha$ immunoreactivity is present in a subpopulation of primary afferents and enhanced after chronic constriction injury (CCI) of the sciatic nerve and arguing that this is attributable to biosynthesis of TNF $\alpha$ in DRG neurons (Shubayev and Myers, 2001; Schafers et al., 2002, 2003b). Contrary to this assumption, our present study provides no evidence for but convincing evidence against TNF $\alpha$ gene expression in DRG neurons. Most importantly, ISH failed to demonstrate constitutive or LPS-induced expression of TNF $\alpha$ mRNA in rat DRG neurons but easily revealed LPS-induced TNF $\alpha$ mRNA expression in DRG non-neuronal cells; using the highly sensitive RT-PCR method on RNA extracts of microdissected DRG neurons and non-neuronal cells, we observed TNF $\alpha$ transcripts only in non-neuronal DRG cells and only after LPS treatment while TNF $\alpha$ transcripts were absent from DRG neurons of normal and LPS-treated rats. Our own attempts to localize $\mathrm{TNF} \alpha$ protein by immunocytochemistry revealed no specific immunostaining in DRG neurons. In fact, nonimmune sera of rabbit and goat instead of rabbit and goat anti-TNF $\alpha$ antisera resulted in the same nonspecific neuronal immunostaining when processed for indirect immunofluorescence. Only $3 \mathrm{hr}$ after LPS treatment we could detect TNF $\alpha$ immunoreactivity in the ED1positive non-neuronal subpopulation, whereas neuronal perikarya exhibited only background staining.

Taken together, the total lack of TNF $\alpha$ mRNA from DRG neurons as unequivocally revealed in this study and the absence of specific TNF $\alpha$ IR from neuronal perikarya strongly indicate that TNF $\alpha$ in DRG is produced in non-neuronal cells but not in neurons. Therefore, the view of TNF $\alpha$ biosynthesis in DRG neurons should be dismissed.

\section{Expression of TNFR $1 \mathrm{mRNA}$ but not of TNFR $2 \mathrm{mRNA}$ in DRG neurons}

Our results obtained from ISH and LCM in combination with RT-PCR provide strong evidence that TNFR1 mRNA but not TNFR2 mRNA is expressed in DRG neurons and that virtually all DRG neurons express TNFR1. The presence of TNFR1 but absence of TNFR2 expression in DRG neurons corresponds well to our observation that TNFR1 but not TNFR2 was expressed in the sensory cell line F11 as revealed by RT-PCR and Western blot
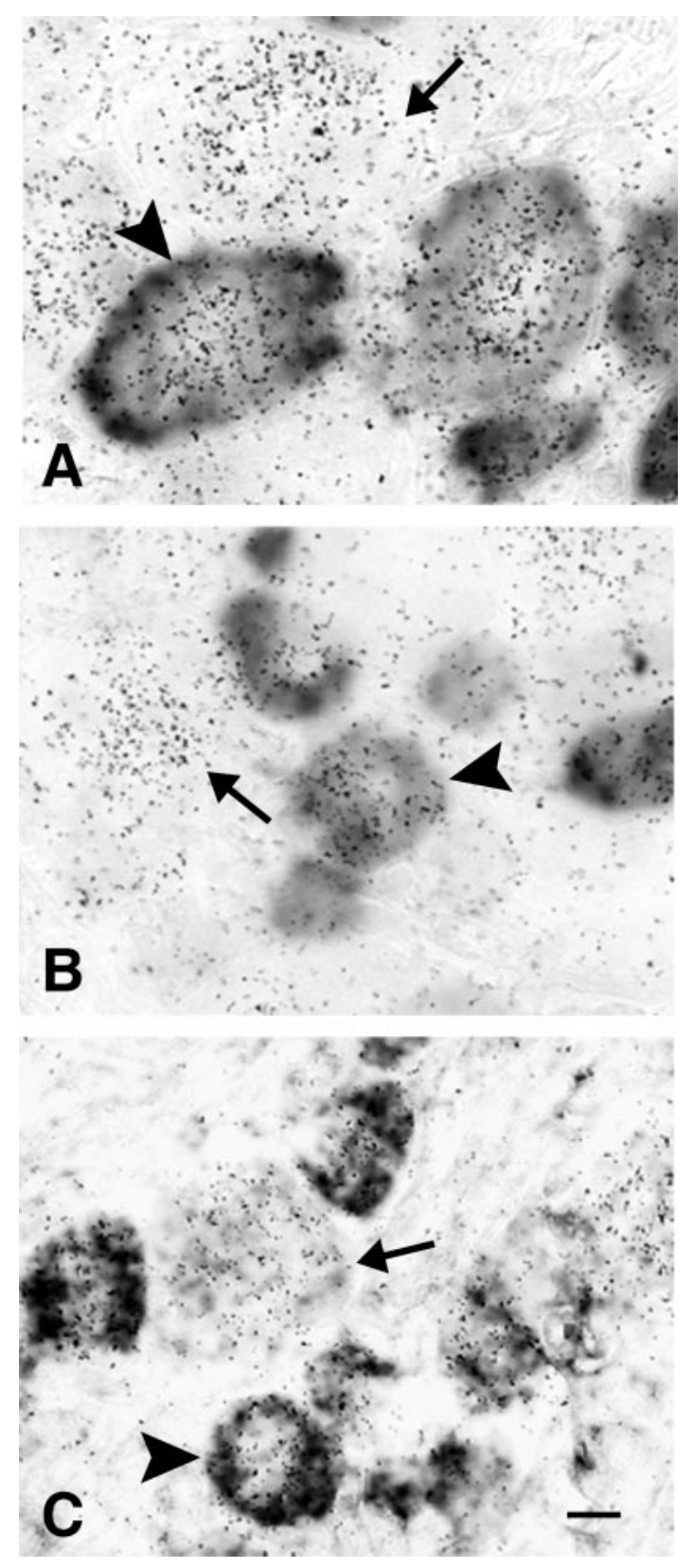

Figure 9. Coexpression of TNFR1 mRNA with $\alpha$ CGRP mRNA, SP mRNA, or VR1 mRNA. Double-labeling in situ hybridization with ${ }^{35} \mathrm{~S}$-labeled probes for TNFR1 and digoxigeninlabeled riboprobes of $\alpha C G R P$ mRNA ( $A$ ), SP mRNA ( $B$ ), or VR1 mRNA ( $C$ reveals the coexpression of TNFR1 with nociceptive markers in presumed pain-transmitting neurons (arrowheads), but also TNFR 1 expression in other sensory neurons (arrows). Exposure time of autoradiograms is $7 \mathrm{~d}$. Scale bar: $C, 10 \mu \mathrm{m}$.

analysis. Our finding of virtually pan-neuronal expression of TNFR1 mRNA in rat DRG is in some contrast to the report that TNFR1 immunoreactivity is only found in subpopulations of small- and large-diameter DRG neurons (Schafers et al., 2003a). TNFR1 mRNA expression has been also found in most if not all neurons of mouse trigeminal ganglia (Cunningham et al., 1997) and in all primary sensory neurons of the trigeminal mesencephalic nucleus of the mouse (Bette et al., 2003), suggesting that neuronal expression of TNFR1 may be a widespread phenomenon in sensory pathways.

The absence of TNFR2 mRNA expression in DRG neurons of normal rats and rats challenged by LPS demonstrated in the 
present study is in contrast to several reports showing positive immunostaining for TNFR2 in small and large DRG neurons of rats and mice with an increase during nerve lesion (Shubayev and Myers, 2001; Pollock et al., 2002; Schafers et al., 2003a). It is puzzling that these reports did not comment on TNFR2 immunostaining in non-neuronal cells of the DRG, where constitutive TNFR2 mRNA was easily detected in the present study. Thus, the concept of biosynthesis of TNFR2 in DRG neurons must be questioned.

\section{Cell-specific plasticity of TNFR1 and TNFR2 expression in the dorsal root ganglion after LPS treatment}

The present study demonstrates that systemic application of LPS enhances the expression of TNFR1 mRNA in DRG neurons and the expression of both TNFR1 and TNFR2 mRNA in DRG non-neuronal cells. In contrast, TNFR2 mRNA expression is absent from DRG neurons and remains absent under LPS challenge. Our previous finding demonstrating expression of the LPS receptor toll like receptor 4 (TLR4) in a subset of rat DRG neurons ( $\mathrm{Li}$ et al., 2002) suggests that increased TNFR1 expression in DRG neurons after LPS may be caused by direct effects of LPS on DRG neurons. The LPS-induced increase of TNFR1 mRNA in DRG neurons may provide a mechanism by which TNF $\alpha$ effects on primary afferents can be amplified.

\section{Possible roles of TNFR1 in DRG neurons and of TNF $\alpha$, TNFR1, and TNFR2 in DRG non-neuronal cells in pain and other sensory functions}

LPS is a potent inducer of proinflammatory cytokines such as TNF $\alpha$, IL-1, and IL- 6 and has been shown to cause hyperalgesia (Wiertelak et al., 1994; Walker et al., 1996; Cahill et al., 1998; Reeve et al., 2000). Thus, LPS-induced expression of TNF $\alpha$ in DRG non-neuronal cells as shown in the present study may be causally related to LPS-induced hyperalgesia. The neuronal expression of TNFR1 but not of TNFR2 in DRG strongly suggests that exogenous and endogenous TNF $\alpha$ from pleiotropic cellular sources is likely to influence primary sensory functions and neurotransmission directly by acting on TNFR1 bearing sensory neurons, at the level of their cell bodies, their intraganglionic collaterals, their collaterals in peripheral nerves, and their peripheral and central terminals (Fig. 10). In fact, in the periphery TNF $\alpha$ is synthesized by a variety of cells during the immune response and under inflammation and in the spinal cord TNF $\alpha$ can be synthesized by and released from glial cells (Watkins et al., 2001). Indeed, neutralizing antibodies against TNFR1 but not against TNFR2 reduce thermal hyperalgesia and mechanical allodynia in the CCI mouse (Sommer et al., 1998), supporting our view that primary sensory neurons are specifically controlled by TNFR1. Intrathecally applied antisense oligodeoxynucleotides to TNFR1 decrease not only TNFR1 protein expression in peripheral nerve terminals of DRG neurons but also reduce inflammatory hyperalgesia in the rat (Parada et al., 2003).

The expression of TNFR1 in small-diameter presumed nociceptive neurons expressing SP, CGRP, or VR1 demonstrated in this study provides evidence how the reported effects of TNF $\alpha$ on nociceptive responses (Watkins et al., 1995; Junger and Sorkin,
2000; Sorkin and Doom, 2000) are exerted directly at the level of distinct classes of primary sensory nociceptive neurons. In fact, TNF $\alpha$ is known to induce the release of SP and CGRP from peripheral terminals (Ding et al., 1995; Hua et al., 1996). Recombinant TNF $\alpha$ excites nociceptors and enhances heat-evoked release of CGRP from peripheral nerve terminals (Opree and Kress, 2000). Given the observation that VR1 neurons express TNFR1 as shown in this study, it is tempting to speculate that TNF $\alpha$ sensitizes VR1 signaling in a similar way as demonstrated for other inflammatory mediators like PGE2 or bradykinin (Sugiura et al., 2002).

Our finding that the expression of the TNFR1 gene is virtually pan-neuronal and not restricted to presumed nociceptive neurons in the rat DRG implies a broader role of TNF $\alpha$ in primary sensory functions than nociception alone as currently assumed. As TNF $\alpha$ contributes to nerve growth factor (NGF)-dependent neuronal cell death during development (Barker et al., 2001), this may also apply to TNFR1 bearing sensory neurons. In fact, neutralizing antibodies against either TNF $\alpha$ or TNFR1 rescued many sensory neurons after NGF deprivation in vitro. Another possibility is that all TNFR1-expressing sensory neurons may function as immunosensors (Weihe et al., 1991) by sensing any TNF $\alpha$ released from a variety of cells in the periphery, either by being in contact with TNF $\alpha$ secreting cells or by being exposed to circulating $\operatorname{TNF} \alpha$. This is likely to be relevant under conditions of inflammatory pain and immune responses during infections accompanied by widespread TNF $\alpha$ synthesis and release and may drive sickness behavior and fatigue syndromes.

\section{References}

Barker V, Middleton G, Davey F, Davies AM (2001) TNFalpha contributes to the death of NGF-dependent neurons during development. Nat Neurosci 4:1194-1198.

Bette M, Schafer MK, van Rooijen N, Weihe E, Fleischer B (1993) Distribution and kinetics of superantigen-induced cytokine gene expression in mouse spleen. J Exp Med 178:1531-1539.

Bette M, Kaut O, Schafer MK, Weihe E (2003) Constitutive expression of p55TNFR mRNA and mitogen-specific up-regulation of TNF alpha and p75TNFR mRNA in mouse brain. J Comp Neurol 465:417-430.

Cahill CM, Dray A, Coderre TJ (1998) Priming enhances endotoxin- 
induced thermal hyperalgesia and mechanical allodynia in rats. Brain Res 808:13-22.

Caterina MJ, Schumacher MA, Tominaga M, Rosen TA, Levine JD, Julius D (1997) The capsaicin receptor: a heat-activated ion channel in the pain pathway. Nature 389:816-824.

Cunha FQ, Poole S, Lorenzetti BB, Ferreira SH (1992) The pivotal role of tumour necrosis factor alpha in the development of inflammatory hyperalgesia. Br J Pharmacol 107:660-664.

Cunningham Jr ET, Stalder AK, Sanna PP, Liu SS, Bloom FE, Howes Jr EL, Campbell IL, Margolis TP (1997) Distribution of tumor necrosis factor receptor messenger RNA in normal and herpes simplex virus infected trigeminal ganglia in the mouse. Brain Res 758:99-106.

Damoiseaux JG, Dopp EA, Calame W, Chao D, MacPherson GG, Dijkstra CD (1994) Rat macrophage lysosomal membrane antigen recognized by monoclonal antibody ED1. Immunology 83:140-147.

Ding M, Hart RP, Jonakait GM (1995) Tumor necrosis factor-alpha induces substance $\mathrm{P}$ in sympathetic ganglia through sequential induction of interleukin-1 and leukemia inhibitory factor. J Neurobiol 28:445-454.

Gordon JR, Galli SJ (1991) Release of both preformed and newly synthesized tumor necrosis factor alpha (TNF-alpha)/cachectin by mouse mast cells stimulated via the Fc epsilon RI. A mechanism for the sustained action of mast cell-derived TNF-alpha during IgE-dependent biological responses. J Exp Med 174:103-107.

Holst O, Ulmer AJ, Brade H, Flad HD, Rietschel ET (1996) Biochemistry and cell biology of bacterial endotoxins. FEMS Immunol Med Microbiol 16:83-104.

Hopkins SJ, Rothwell NJ (1995) Cytokines and the nervous system. I: Expression and recognition. Trends Neurosci 18:83-88.

Hua XY, Chen P, Fox A, Myers RR (1996) Involvement of cytokines in lipopolysaccharide-induced facilitation of CGRP release from capsaicinsensitive nerves in the trachea: studies with interleukin-1beta and tumor necrosis factor-alpha. J Neurosci 16:4742-4748.

Ignatowski TA, Covey WC, Knight PR, Severin CM, Nickola TJ, Spengler RN (1999) Brain-derived TNFalpha mediates neuropathic pain. Brain Res 841:70-77.

Junger H, Sorkin LS (2000) Nociceptive and inflammatory effects of subcutaneous TNFalpha. Pain 85:145-151.

Li Y, Ji A, Schäfer MK (2002) Toll-like receptor 4 is expressed by peptidergic presumed nociceptive neurons in rat dorsal root ganglion. Soc Neurosci Abstr 46:19.

Lindenlaub T, Teuteberg P, Hartung T, Sommer C (2000) Effects of neutralizing antibodies to TNF-alpha on pain-related behavior and nerve regeneration in mice with chronic constriction injury. Brain Res 866: $15-22$.

Liu B, Li H, Brull SJ, Zhang JM (2002) Increased sensitivity of sensory neurons to tumor necrosis factor alpha in rats with chronic compression of the lumbar ganglia. J Neurophysiol 88:1393-1399.

MacEwan DJ (2002) TNF receptor subtype signalling: differences and cellular consequences. Cell Signal 14:477-492.

Mika J, Li Y, Weihe E, Schafer MK (2003) Relationship of pronociceptin/ orphanin FQ and the nociceptin receptor ORL1 with substance P and calcitonin gene-related peptide expression in dorsal root ganglion of the rat. Neurosci Lett 348:190-194.

Murphy PG, Grondin J, Altares M, Richardson PM (1995) Induction of interleukin-6 in axotomized sensory neurons. J Neurosci 15:5130-5138.

Murwani R, Hodgkinson S, Armati P (1996) Tumor necrosis factor alpha and interleukin- 6 mRNA expression in neonatal Lewis rat Schwann cells and a neonatal rat Schwann cell line following interferon gamma stimulation. J Neuroimmunol 71:65-71.

Nadeau S, Rivest S (1999) Effects of circulating tumor necrosis factor on the neuronal activity and expression of the genes encoding the tumor necrosis factor receptors (p55 and p75) in the rat brain: a view from the bloodbrain barrier. Neuroscience 93:1449-1464.

Nohr D, Schafer MK, Persson S, Romeo H, Nyberg F, Post C, Ekstrom G, Weihe E (1999) Calcitonin gene-related peptide gene expression in collagen-induced arthritis is differentially regulated in primary afferents and motoneurons: influence of glucocorticoids. Neuroscience 93:759-773.

Opree A, Kress M (2000) Involvement of the proinflammatory cytokines tumor necrosis factor- alpha, IL-1 beta, and IL-6 but not IL-8 in the development of heat hyperalgesia: effects on heat-evoked calcitonin generelated peptide release from rat skin. J Neurosci 20:6289-6293.

Parada CA, Yeh JJ, Joseph EK, Levine JD (2003) Tumor necrosis factor receptor type-1 in sensory neurons contributes to induction of chronic enhancement of inflammatory hyperalgesia in rat. Eur J Neurosci 17:1847-1852.

Platika D, Boulos MH, Baizer L, Fishman MC (1985) Neuronal traits of clonal cell lines derived by fusion of dorsal root ganglia neurons with neuroblastoma cells. Proc Natl Acad Sci USA 82:3499-3503.

Pollock J, McFarlane SM, Connell MC, Zehavi U, Vandenabeele P, MacEwan DJ, Scott RH (2002) TNF-alpha receptors simultaneously activate $\mathrm{Ca}^{2+}$ mobilisation and stress kinases in cultured sensory neurones. Neuropharmacology 42:93-106.

Reeve AJ, Patel S, Fox A, Walker K, Urban L (2000) Intrathecally administered endotoxin or cytokines produce allodynia, hyperalgesia and changes in spinal cord neuronal responses to nociceptive stimuli in the rat. Eur J Pain 4:247-257.

Schafer MK-H, Herman JP, Watson SJ (1993) In situ hybridization histochemistry. In: Imaging drug action in the brain (Edythe D. London, ed), pp 337-378. Boca Raton: CRC.

Schafers M, Geis C, Brors D, Yaksh TL, Sommer C (2002) Anterograde transport of tumor necrosis factor-alpha in the intact and injured rat sciatic nerve. J Neurosci 22:536-545.

Schafers M, Sorkin LS, Geis C, Shubayev VI (2003a) Spinal nerve ligation induces transient upregulation of tumor necrosis factor receptors 1 and 2 in injured and adjacent uninjured dorsal root ganglia in the rat. Neurosci Lett 347:179-182.

Schafers M, Geis C, Svensson CI, Luo ZD, Sommer C (2003b) Selective increase of tumour necrosis factor-alpha in injured and spared myelinated primary afferents after chronic constrictive injury of rat sciatic nerve. Eur J Neurosci 17:791-804.

Shubayev VI, Myers RR (2001) Axonal transport of TNF-alpha in painful neuropathy: distribution of ligand tracer and TNF receptors. J Neuroimmunol 114:48-56.

Sommer C, Schafers M (1998) Painful mononeuropathy in C57BL/Wld mice with delayed wallerian degeneration: differential effects of cytokine production and nerve regeneration on thermal and mechanical hypersensitivity. Brain Res 784:154-162.

Sommer C, Schmidt C, George A (1998) Hyperalgesia in experimental neuropathy is dependent on the TNF receptor 1. Exp Neurol 151:138-142.

Sorkin LS, Doom CM (2000) Epineurial application of TNF elicits an acute mechanical hyperalgesia in the awake rat. J Peripher Nerv Syst 5:96-100.

Sugiura T, Tominaga M, Katsuya H, Mizumura K (2002) Bradykinin lowersthe threshold temperature for heat activation of vanilloid receptor 1 J Neurophysiol 88:544-548.

Wagner R, Myers RR (1996) Schwann cells produce tumor necrosis factor alpha: expression in injured and non-injured nerves. Neuroscience 73:625-629.

Walker K, Dray A, Perkins M (1996) Hyperalgesia in rats following intracerebroventricular administration of endotoxin: effect of bradykinin B1 and B2 receptor antagonist treatment. Pain 65:211-219.

Watkins LR, Wiertelak EP, Goehler LE, Smith KP, Martin D, Maier SF (1994) Characterization of cytokine-induced hyperalgesia. Brain Res 654:15-26.

Watkins LR, Goehler LE, Relton J, Brewer MT, Maier SF (1995) Mechanisms of tumor necrosis factor-alpha (TNF-alpha) hyperalgesia. Brain Res 692:244-250.

Watkins LR, Milligan ED, Maier SF (2001) Spinal cord glia: new players in pain. Pain 93:201-205.

Weihe E, Nohr D, Michel S, Muller S, Zentel HJ, Fink T, Krekel J (1991) Molecular anatomy of the neuro-immune connection. Int J Neurosci 59:1-23.

Wesselingh SL, Takahashi K, Glass JD, McArthur JC, Griffin JW, Griffin DE (1997) Cellular localization of tumor necrosis factor mRNA in neurological tissue from HIV-infected patients by combined reverse transcriptase/ polymerase chain reaction in situ hybridization and immunohistochemistry. J Neuroimmunol 74:1-8.

Wiertelak EP, Smith KP, Furness L, Mooney-Heiberger K, Mayr T, Maier SF, Watkins LR (1994) Acute and conditioned hyperalgesic responses to illness. Pain 56:227-234. 